\title{
DIEL VARIATION OF FISH COMMUNITY IN SANDY BEACHES OF SOUTHEASTERN BRAZIL
}

\author{
Luiz Ricardo Gaelzer ${ }^{1,2}$ and Ilana R. Zalmon ${ }^{2}$
}

${ }^{1}$ Instituto de Estudos do Mar Alte Paulo Moreira - IEAPM

Departamento de Oceanografia - Seção de Recursos Vivos

(Rua Kioto 253, 289300-000 Arraial do Cabo, RJ, Brasil)

gaelzermar@terra.com.br

${ }^{2}$ Universidade Estadual do Norte Fluminense - Laboratório de Ciências Ambientais (Av. Alberto Lamego 2000, Horto, 28013-600, Campos dos Goytacazes, RJ, Brasil) ilana@uenf.br

\section{A B S T R A C T}

Fish living in coastal waters present behavior patterns ruled by environmental light levels. Diel variations in fish community structure were investigated at Arraial do Cabo surf zone $\left(22^{\circ} 58^{\prime} \mathrm{S}\right.$, $42^{\circ} 011^{\prime} \mathrm{W}$ ). From September/2001 to August $/ 2002$ monthly sampling consisted of 12 hauls of a beach seine during the day and at night at Praia dos Anjos, Praia Grande and Prainha beaches. Different temporal distribution patterns of the ichthyc community were recorded. At Praia dos Anjos, total richness was higher at night while the average number of species, CPUE, Margalef's richness and Shannon diversity were generally higher during the day. We believe that this pattern was caused by the displacement of some species such as Harengula clupeola, Trachinotus carolinus and Umbrina coroides at night to deeper areas searching for food or for predator avoidance. At Praia Grande and Prainha the average number of species, CPUE, richness and diversity indexes were generally higher at night with the dominant species $H$. clupeola, Pomatomus saltatrix and Sardinella brasiliensis. It is suggested that the main factor to diel variation is the protection against predators due to darkness, making visualization of the prey difficult, besides the presence of seasonal macroalgae beds at Prainha, which might function as a food area for piscivorous fishes due to the proximity of larger individuals in shallower water especially at night.

\section{R ESUMO}

Peixes que vivem em águas costeiras marinhas exibem modelos de comportamento que são regulados pelos níveis de luz do ambiente. A variação nictemeral na estrutura da comunidade de peixes de zona de arrebentação foi investigada na região de Arraial do Cabo $\left(22^{\circ} 58^{\prime} \mathrm{S}, 42^{\circ} 01^{\prime} \mathrm{W}\right)$. De setembro/2001 a agosto/2002 foram realizadas coletas mensais, sendo efetuadas 12 arrastos utilizando cerco de praia nos períodos diurnos e noturnos na Praia dos Anjos, Praia Grande e Prainha. Diferentes padrões de distribuição da comunidade ictíca foram registrados. Na Praia dos Anjos, o número de espécies foi superior no período noturno. Já o número médio de espécies, CPUE, riqueza de Margalef e diversidade de Shannon foram, em geral, superiores no período diurno. Este padrão de comportamento foi causado pelo deslocamento noturno de algumas espécies, tais como Harengula clupeola, Trachinotus carolinus e Umbrina coroides para áreas mais profundas a procura de alimento ou para evitar predadores. Na Praia Grande e na Prainha, o número médio de espécies, CPUE e os índices de riqueza e diversidade foram, em geral, superiores no período noturno, com a dominância das espécies H. clupeola, Pomatomus saltatrix e Sardinella brasiliensis. Sugere-se que o principal fator para esta variação nictemeral seja a proteção contra predadores devido à escuridão, tornando a visualização da presa mais difícil, além da presença de bancos sazonais de macroalgas na Prainha, que pode funcionar como uma área de alimentação para peixes piscívoros devido ao encontro de uma grande quantidade de indivíduos em águas rasas especialmente à noite.

Descriptors: Ichthyofauna, Surf zone, Community structure, Diurnal variation.

Descritores: Ictiofauna, Zona de arrebentação, Estrutura de comunidade, Variação diuturna.

\section{INTRODUCTION}

Day and night succession has a strong influence on the relative abundance of several species, changing the composition and richness of fish assemblages (CLARK et al., 1996a). Fish living in coastal waters presents behavior patterns ruled in particular by the day-night cycle (POTTS, 1990), where the change in temperature and solar radiation influences feeding activity and metabolical and behavioral responses including protection from 
predators. These behaviors allow the characterization of the species as diurnal or nocturnal through observation of higher activity or rest periods; the latter including searching for shelter (HOBSON, 1965). At night, fish leaves their shelters more frequently and this could explain the higher captures in shallow waters during this period (PATERSON; WHITFIELD, 2000), although the benefit of net avoidance in daylight by several species (HORN, 1980).

The effect of light levels on circadian rhythms of fish in the surf zone involve 24 hour studies that have only fairly recently begun to be done (CLARK et al., 1996b; GIBSON et al., 1996; GODEFROID, HOFSTAETTER; SPACH, 1997; PESSANHA; ARAÚJO, 2003), due to the difficulties in extensive night sampling in this zone which frequently has strong hydrodynamics.

The surf zone of sandy beaches is dominated by a small number of fish species, generally juveniles (AUYVAZIAN; HYNDES, 1995), due to the rich food resources, relatively low number of predators and high turbidity of the shallow waters (BLABER ; BLABER, 1980; LASIAK, 1986; GIANNINI and PAIVA-FILHO, 1995; CLARK, 1996a,b). In Brazil, studies in this zone have been done mainly in the south and southeastern coast (CUNHA, 1981; PAIVA-FILHO; TOSCANO, 1987; MONTEIRO-NETO et al., 1990; MONTEIRO-NETO; MUSICK, 1994; PEREIRA, 1994; SAUL; CUNNINGHAM, 1995; GIANINNI; PAIVA-FILHO, 1995; LOPES et al., 1999; ARAÚJO; AZEVEDO, 2001; GOMES et al., 2003; GODEFROID et al., 1997, 2004; SPACH et al., 2004) generally related to spatial and temporal variations of the fish community structure, trophic ecology (TEIXEIRA et al., 1992;CHAVES; BOUCHEREAU, 2004), nictemeral variation (PESSANHA et al., 2003; PESSANHA; ARAÚJO, 2003; BARREIROS et al., 2004) and wave exposure (GAELZER ; ZALMON, 2003).

Studies of fish communities in Arraial do Cabo have been related to rocky coasts (VIANNA, 1997; FERREIRA et al., 1994, 1998) and to benthic or demersal fish (FAGUNDES NETTO \& GAELZER, 1991). Gaelzer and Zalmon (2003) studied the influence of the beach morphological dynamics and tide level on the fish community structure of this surf zone (GAELZER, 2005).

In the present study we hypothesized that the fish community show a diel variation in the surf zone at Arraial do Cabo beaches. We expected higher richness, diversity and CPUE (g/haul) values at night caused by the proximity of larger piscivorous adults.

\section{Material And Methods \\ Study Area}

In the region of Cabo Frio $\left(22^{\circ} 58^{\prime} \mathrm{S}\right.$, $42^{\circ} 01^{\prime} \mathrm{W}$ ), there is a coastal upwelling mainly from November to March due to a combination of factors as the change on the Brazilian current direction, sea floor topography and Ekman transport caused by the predominant E-NE winds in the area. This result on nutrient rich waters (VALENTIN, 1984) and allows the growth of an abundant and diverse marine fauna and flora (CASTRO et al., 1995; GUIMARAENS; COUTINHO, 1996; ORNELLAS; COUTINHO, 1998; FERREIRA et al., 2001), which supports an important fishing sector.

Three beaches $4 \mathrm{~km}$ distant with different environmental characteristics such as wave exposure, morphodynamics and upwelling influence were chosen at Arraial do Cabo: Praia Grande beach is very exposed to wave action (Fig. 1) with medium size sand (GAELZER, 2005) and direct influence of upwelling; Praia dos Anjos beach (Fig. 1) is located in a protected bay from direct wave action with medium to fine sand (Gaelzer, op. cit.) and is least affected by upwelling; Prainha beach (Figs 1; 4) has moderately high wave action with medium to fine sand (GAELZER, op. cit.) and the upwelling is very rare; there is an extense macroalgal bank on the right side approximadely $400 \mathrm{~m}$ from the beach (ORNELLAS; COUTINHO, 1998). Water transparency of all three beaches is greater than $2.00 \mathrm{~m}$.

Water temperature $(\mathrm{T})$ and salinity $(\mathrm{S})$ were monitored monthly during three days prior to the sampling date with a digital thermometer and rephratometer, respectively. According to TS pair position (MIRANDA; KATSURAGAWA, 1991; AIDAR et al., 1993), these environmental parameters might be an indicative of upwelling occurrence and different water masses. The surf zone ichthyofauna variation related to tide levels at the three studied beaches was investigated by GAELZER (2005).

Fish sampling was carried out monthly from September/2001 to August/2002 through three trawls $300 \mathrm{~m}$ distant at less than $1.5 \mathrm{~m}$ deep at each beach during diurnal $(06: 00$ to $12: 00 \mathrm{~h})$ and nocturnal (18:00 to $24: 00 \mathrm{~h}$ ) periods using a beach seine of $25.0 \mathrm{~m}$ length, $2.50 \mathrm{~m}$ height and $10 \mathrm{~mm}$ mesh. Each trawl covered a distance of $100 \mathrm{~m}$ to standardize the sampling effort. Trawls were done parallel to the beach in accordance with tide level to obtain sample from low and high tide. On each sampling date six trawls were made during the day time and six at night for a total of twelve trawls each month at each beach. 


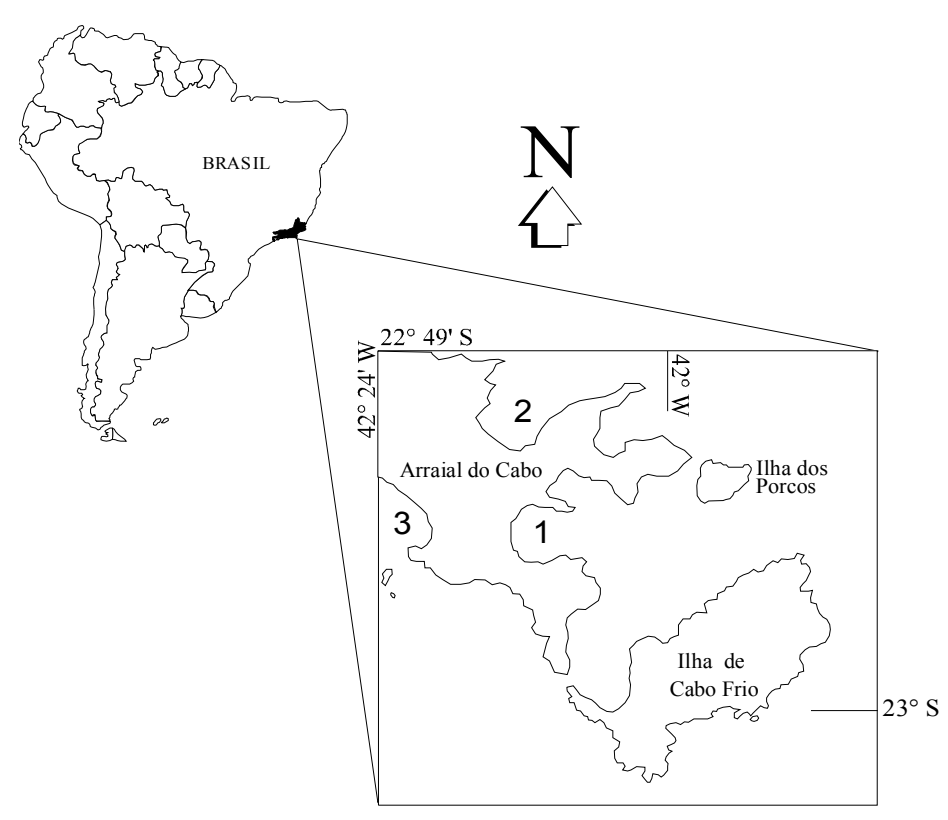

Fig. 1. Location of the studied beaches at Arraial do Cabo, southeastern Rio de Janeiro (1 - Praia dos Anjos beach, 2 - Prainha beach, 3 - Praia Grande beach).

The hourly sequence of the trawls was altered among beaches to reduce systematic sampling errors both during the day and at night.

The fish were identified (FIGUEIREDO; MENEZES, 1978; 1980; 2000; MENEZES; FIGUEIREDO, 1980; 1985) and the total length $(\mathrm{mm})$ and weight $(0.1 \mathrm{~g})$ recorded for each specimen.

The species abundance variability was assessed through the catch per unit effort (CPUE) in number (individuals/haul) and weight (grams/haul). Variation in the composition and structure of the community were investigated using Margalef's richness index, Shannon's diversity (number of individuals) and Simpson's dominance (number of individuals) (ZAR, 1984). The fish assemblages' differences between diurnal and nocturnal periods at each beach were determined by test $t$ - Student (ZAR, 1984). Average monthly values were previously $\log$ transformed, and tested for normality and homocedasticity.

The comparative analysis of the fish community temporal patterns included a cluster analysis (UPGMA) and a multi dimensional scaling (MDS) using the Bray-Curtis similarity coefficient for CPUE values (individuals/haul). The matrix included all the species that contributed with at least $5 \%$ of the total capture and if they were present in at least $25 \%$ of the catches. The data were square root transformed to reduce the influence of the most abundant species. The adequacy of the sample configuration in the MDS analysis was obtained by stress results. Stress values under 0.05 give an excellent representation with no probability of misinterpretation (CLARK; WARWICK, 1994).

Similarity percentages procedure (SIMPER) defined the percentual contribution of the most abundant species between and within groups of the cluster analysis (CLARK; WARWICK, 1994). A cut-off of cumulative dissimilarity of $50 \%$ was applied. Data analysis was performed with PRIMER software.

The seasons of the studied year are referred as spring (September-October-November), summer (December-January-February), autumn (MarchApril-May) and winter (June-July-August).

\section{RESUlts}

\section{Environmental Parameters}

At Praia dos Anjos beach the surface water temperature during both diurnal and nocturnal periods varied from 22 to $26^{\circ} \mathrm{C}$, with higher values during the day and in summer months (maximum of $24^{\circ} \mathrm{C}$ in January) and lower ones in the winter (between $20^{\circ}$ and $23^{\circ} \mathrm{C}$ ). Similar values of salinity (around 35.5) were recorded in diurnal and nocturnal periods, except in March/2002 and June/2002 due to high pluviometric precipitation. According to TS pair position, the water masses show characteristics of Coastal (CW) and Tropical Water (TW) during both 
periods during most part of the year, without an upwelling effect.

At Praia Grande beach, the water temperature varied from $14^{\circ}$ to $26^{\circ} \mathrm{C}$ during both periods. Higher temperatures occurred from May to June/2002 and lower ones during the winter months. Similar values of salinity were also recorded in diurnal and nocturnal periods, around 35.5, with greater differences in December/2001 and June/2002. Temperature and salinity results reflect a characteristic water mass of the South Atlantic Central Water in both periods, indicating the upwelling phenomenon.

At Prainha beach, the water temperature varied from $22^{\circ}$ to $26^{\circ} \mathrm{C}$ in both periods with higher values in November/2001 and from March to April/2002 $\left(25^{\circ} \mathrm{C}\right)$, and lower in September/2001 $\left(20^{\circ} \mathrm{C}\right)$. The salinity showed similar values in diurnal and nocturnal periods, varying from 35 to 36 . The above results indicate water masses with characteristics of Coastal $(\mathrm{CW})$ and Tropical Water (TW). The presence of upwelling was not recorded at this beach.

\section{Diel VARIATION \\ Praia dos Anjos Beach}

At Praia dos Anjos beach, a total of 8751 fish of 51species were caught from September/2001 to August/2002, comprising 29 families and a biomass of 81784.8 grams in diurnal and nocturnal periods. The diurnal catches had 35 species, which contributed with $74 \%$ of the total number of individuals and $54 \%$ of the biomass, with five exclusive species. The nocturnal catches had 44 species, which contributed with $26 \%$ of the total number of individuals and $46 \%$ of the biomass, with 14 exclusive species. The total number of species and the exclusive ones were higher in the nocturnal period (Table 1).

Table 1. Total number of individuals (n) and weight (g) of fish species in Praia dos Anjos beach in diurnal and nocturnal period (September/01 to August/02).

\begin{tabular}{|c|c|c|c|c|}
\hline Species & Diurnal (n) & Diurnal (g) & Nocturnal (n) & Nocturnal (g) \\
\hline Narcine brasiliensis & - & 451.0 & 8 & - \\
\hline Discopyge tschuddi & - & 2106.4 & 1 & - \\
\hline Elops saurus & - & 501.8 & 3 & - \\
\hline Albula vulpes & 55 & 757.0 & 88 & 3707.9 \\
\hline Opisthonema oglinum & 189 & 1233.4 & 2 & 30.3 \\
\hline Harengula clupeola & 3.503 & 19203.4 & 528 & 3880.3 \\
\hline Sardinella brasiliensis & - & - & 194 & 1260.7 \\
\hline Synodus foetens & 2 & 19.0 & - & - \\
\hline Polydactylus oligodon & 14 & 111.2 & 13 & 112.9 \\
\hline Strongylura marina & - & - & 1 & 114.1 \\
\hline Strongylura timиси & 1 & 6.7 & 2 & 117.6 \\
\hline Odontesthes bonariensis & 3 & 46.4 & - & - \\
\hline Fistularia tabacaria & 1 & 37.5 & - & - \\
\hline Prionotus punctatus & 6 & 113.7 & 9 & 71.9 \\
\hline Dactylopterus volitans & 250 & 3126.9 & 104 & 1244.6 \\
\hline Centropomus paralelus & - & - & 3 & 1179.9 \\
\hline Diplectrum formosum & - & - & 1 & 7.2 \\
\hline Pomatomus saltatrix & 150 & 1077.6 & 153 & 2360.1 \\
\hline Caranx latus & 101 & 1170.2 & 1 & 15.7 \\
\hline Chloroscombrus chrysurus & 1 & 1.3 & - & - \\
\hline Oligoplites saurus & - & - & 3 & 89.3 \\
\hline Selene vomer & 14 & 24.1 & 1 & 3.1 \\
\hline Trachinotus carolinus & 1148 & 6340.0 & 729 & 4017.9 \\
\hline Trachinotus falcatus & 4 & 4.9 & 8 & 91.1 \\
\hline Trachinotus goodei & 293 & 4204.8 & 61 & 1409.3 \\
\hline Eucinostomus argenteus & 391 & 3669.1 & 65 & 2.829 .3 \\
\hline
\end{tabular}


Table 1. Continued.

\begin{tabular}{|c|c|c|c|c|}
\hline Species & Diurnal (n) & Diurnal (g) & Nocturnal (n) & Nocturnal (g) \\
\hline Diapterus rhombeus & 1 & 90.7 & 1 & 166.3 \\
\hline Boridia grossidens & 7 & 44.5 & 20 & 143.0 \\
\hline Haemulon steindachneri & - & - & 1 & 2.1 \\
\hline Orthopristis ruber & - & - & 6 & 1169.7 \\
\hline Conodon nobilis & - & - & 2 & 20.5 \\
\hline Diplodus argenteus & 4 & 62.2 & 1 & 21.2 \\
\hline Menticirrhus americanus & 8 & 45.1 & 9 & 138.2 \\
\hline Menticirrhus littoralis & 26 & 603.6 & 29 & 638.0 \\
\hline Umbrina coroides & 261 & 2114.4 & 183 & 3793.2 \\
\hline Stellifer brasiliensis & 3 & 12.2 & 3 & 15.9 \\
\hline Pseudupeneus maculatus & 2 & 473.0 & 3 & 122.0 \\
\hline Chaetodipterus faber & - & - & 4 & 22.0 \\
\hline Mugil curema & 8 & 1079.2 & 8 & 919.3 \\
\hline Mugil liza & - & - & 1 & 209.5 \\
\hline Mugil platanus & 1 & 508.9 & - & - \\
\hline Sphyraena tome & 3 & 6.7 & - & - \\
\hline Astroscopus ygraecum & 14 & 452.0 & 1 & 126.1 \\
\hline Citharichthys arenaceus & 1 & 0.5 & 2 & 8.8 \\
\hline Citharichthys macrops & 1 & 1.4 & 1 & 1.2 \\
\hline Symphurus trewavase & - & - & 1 & 6.8 \\
\hline Stephanolepis hispidus & 26 & 19.5 & 1 & 6.4 \\
\hline Stephanolepis maculatus & 1 & 4.5 & - & - \\
\hline Lagocephalus laveigatus & - & - & 1 & 1.8 \\
\hline Cyclichthys spinosus & 4 & 105.0 & 3 & 363.0 \\
\hline Sphoeroides spengleri & - & - & 3 & 1537.9 \\
\hline Total & 6497 & 46770 & 2254 & 35033 \\
\hline
\end{tabular}

A similar temporal variation was recorded monthly, with a tendency of higher values in the summer months and during the day (Fig. 2a). The CPUE (number of individuals/haul) was significantly higher during the day $(p=0.03)$, mainly from December/2001 to April/2001, with values up to five times higher (Fig. 2b). The high number of individuals of Harengula clupeola influenced this difference. In relation to the CPUE ( $\mathrm{g} / \mathrm{haul}$ ), a similar temporal pattern was observed in the diurnal and nocturnal periods (Fig. 2c), with significantly higher values during the day in February and March $(p=$ 0.04). Richness and diversity indexes were very similar for both periods, with higher values generally in the summer (Fig. 2d, 2e). The Simpson dominance showed higher values generally during the day, with no significant differences (Fig. 2f).

The representative cluster of the CPUE (number of individuals/haul) in diurnal and nocturnal periods during the study period showed two main groups connected at a similarity level of $50 \%$, which characterized a diel variation (Fig. 3). Group I was formed mainly by the diurnal period of the summer and fall months. Group II included the nocturnal period of the winter, fall and part of the summer months. In the ordination analysis, the separation of the sampling months in both periods corresponded to the cluster analysis pattern (Fig. 3). The moderately high stress level of 0.15 indicates that the distances on the plane do not adequately represent the similarities. 

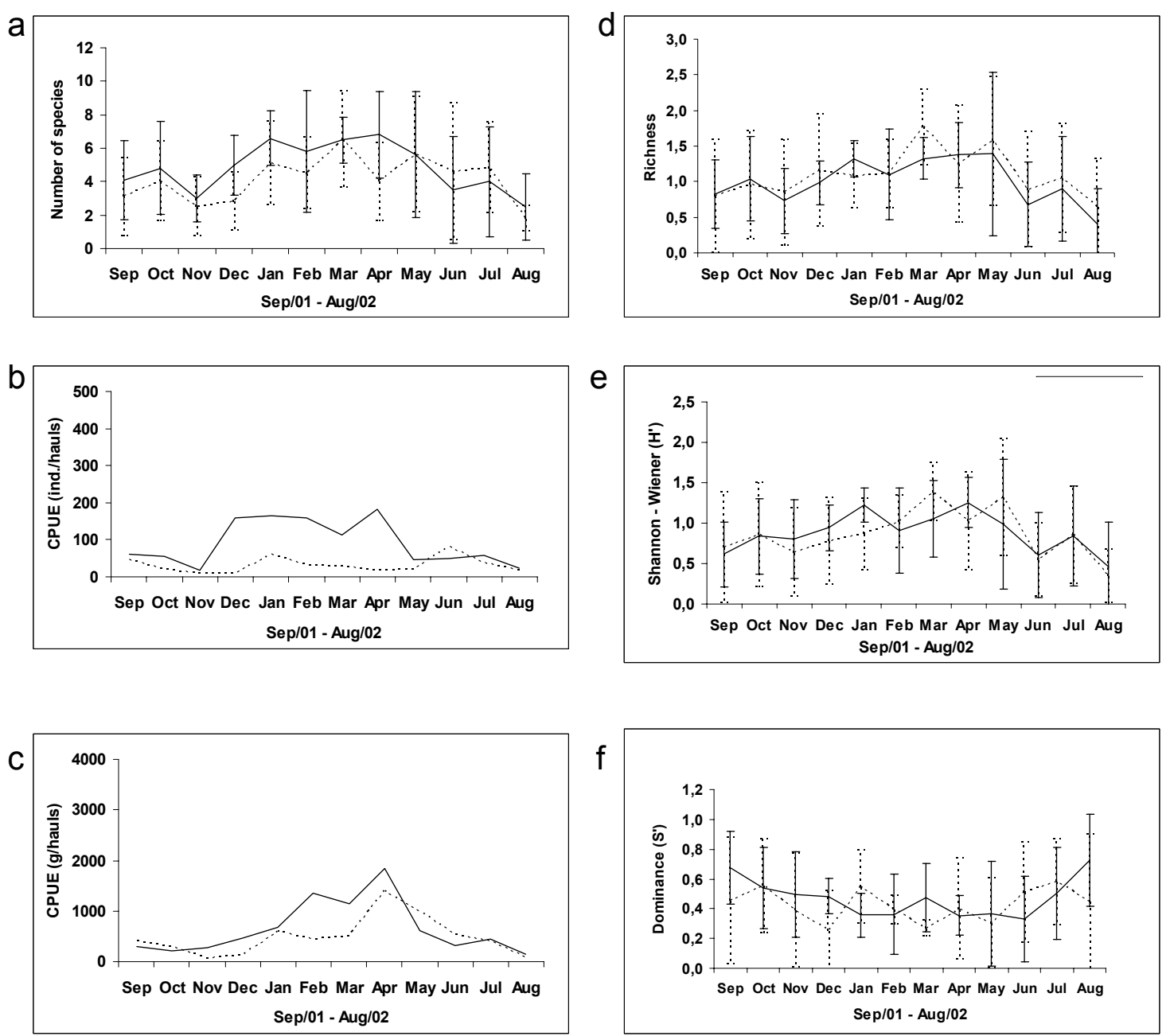

Fig. 2. Temporal variation of average species numbers (a), CPUE ((individuals/haul) (b), CPUE (grams/haul) (c), Margalef's richness (d), Shannon's diversity (e) and Simpson's dominance (f) in diurnal (-) and nocturnal ( ) periods at Praia dos Anjos beach (September/01 to Agust/02).

The analytical method SIMPER indicates that Group I defined by the cluster analysis presented an average similarity of $59 \%$ and the species, which contributed most was H. clupeola (75\%). Group II presented a similarity of $47 \%$, with Trachinotus carolinus as the principal species $(52 \%)$. H. clupeola was the main responsible for the dissimilarity between both groups, contributing with $62 \%$.

\section{Praia Grande Beach}

At Praia Grande beach, a total of 2779 fish were captured, comprising 14 families and 23 species and a total biomass of 20113 grams. During the diurnal period, 12 species were caught, contributing with $43 \%$ of the total number of fish caught and $35 \%$ of the biomass, with five exclusive species. The nocturnal samplings had 18 species, which corresponded to $57 \%$ of the total number of individuals and $65 \%$ of the biomass caught, with 11 exclusive species (Table 2).

The number of species was generally higher in the nocturnal period (Fig. 4a) with significant differences in July and August/2002 ( $p=$ $0.03)$. The highest CPUEs $(p=0.02$ in January/02), Margalef richness and Shannon's diversity occurred in the nocturnal period (Fig. 4b, 4c, 4d, 4e). Simpson's dominance was similar in both periods (Fig. 4f). 


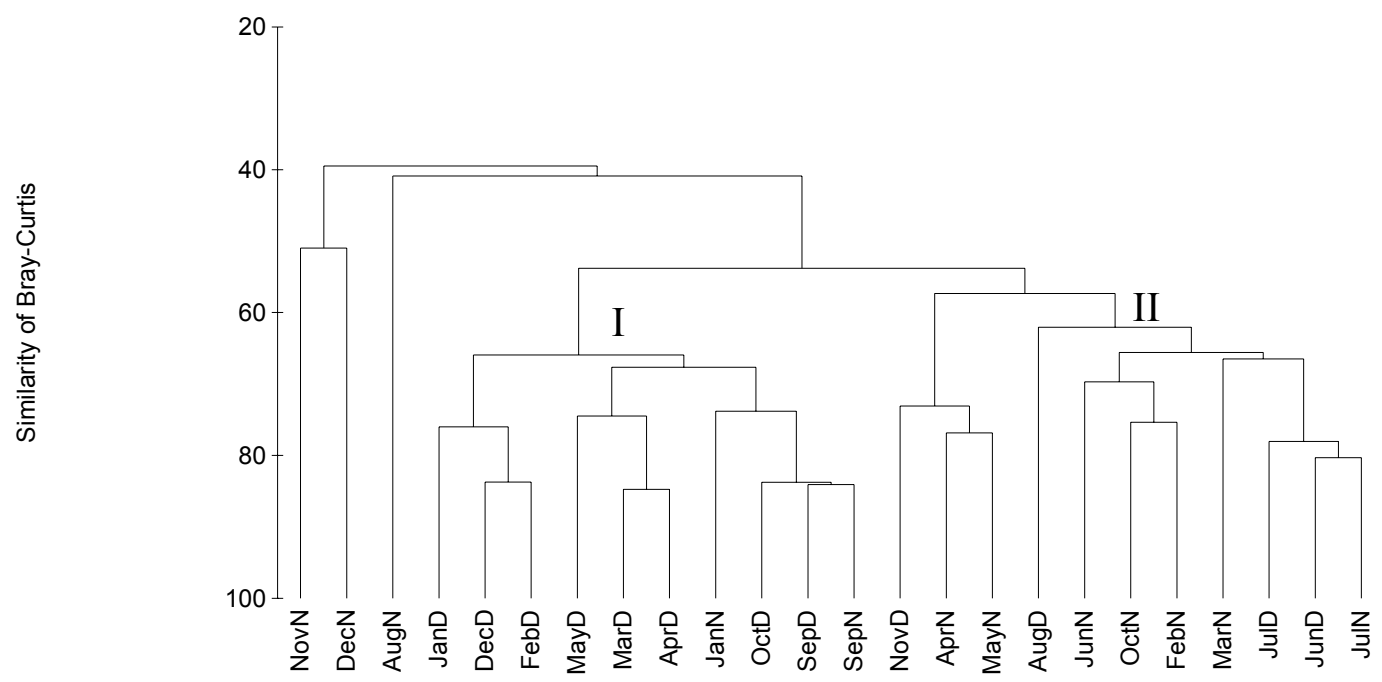

(Sept/01-Aug/02)

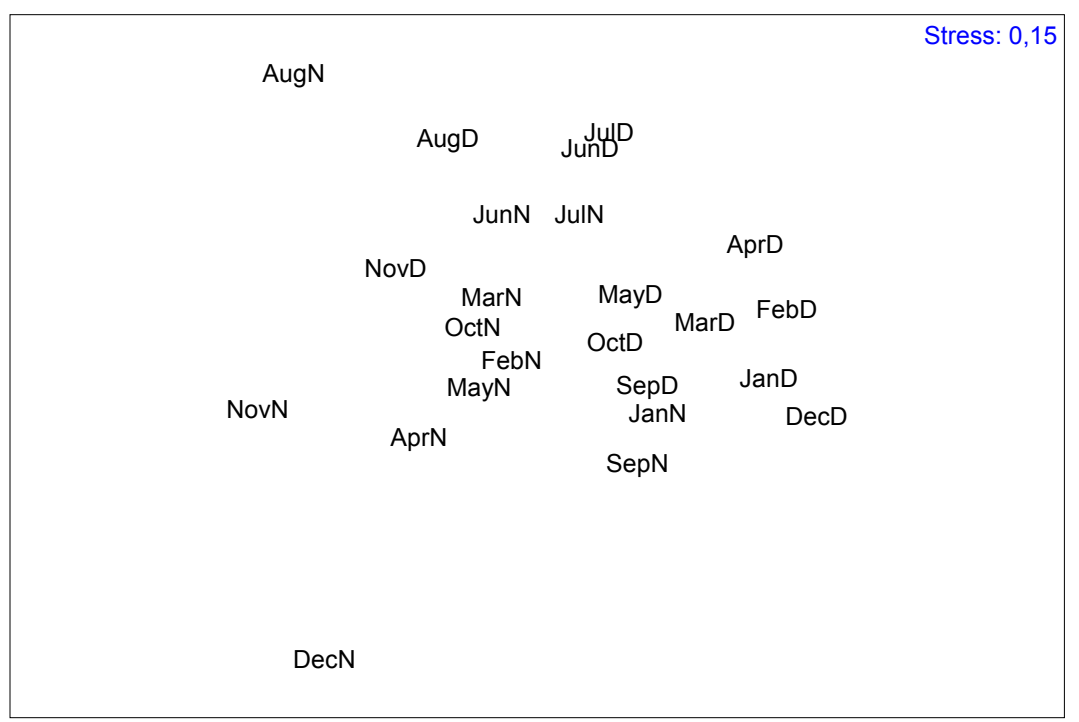

Fig. 3. Cluster analysis (Bray Curtis's similarity coefficient - UPGMA method) and Non-Metric Dimensional Scaling - MDS Ordination method based on CPUE data (individuals/haul) of the main species at Praia dos Anjos beach in diurnal and nocturnal periods (September/01 to August/02). 
Table 2. Total number of individuals (n) and weight (g) of fish species in Praia Grande beach in diurnal and nocturnal periods (September/01 to August/02).

\begin{tabular}{|c|c|c|c|c|}
\hline Species & Diurnal (n) & Diurnal (g) & Nocturnal (n) & Nocturnal (g) \\
\hline Caranx latus & 20 & 205.9 & - & - \\
\hline Citharichthys arenaceus & - & - & 2 & 142.8 \\
\hline Dactylopterus volitans & - & - & 609 & 3126.3 \\
\hline Diapterus rhombeus & 2 & 168.6 & - & - \\
\hline Diplodus argenteus & 95 & 615.6 & 41 & 812.1 \\
\hline Eucinostomus argenteus & 209 & 1913.9 & 1 & 10.5 \\
\hline Harengula clupeola & 482 & 2262.0 & 247 & 1780.4 \\
\hline Menticirrhus americanus & - & - & 1 & 2.6 \\
\hline Menticirrhus littoralis & - & - & 2 & 9.4 \\
\hline Mugil curema & - & - & 4 & 273.8 \\
\hline Mugil liza & 5 & 607.0 & 1 & 412.8 \\
\hline Mugil platanus & 2 & 152.3 & - & - \\
\hline Percophis brasiliensis & - & - & 1 & 321.8 \\
\hline Pomatomus saltatrix & 4 & 24.8 & 254 & 1574.7 \\
\hline Prionotus punctatus & - & - & 5 & 1275.9 \\
\hline Sardinella brasiliensis & 48 & 127.3 & 127 & 906.2 \\
\hline Selene vomer & 1 & 1.1 & - & - \\
\hline Stephanolepis hispidus & - & - & 1 & 1.1 \\
\hline Symphurus papilosum & - & - & 1 & 285.6 \\
\hline Trachinotus carolinus & 319 & 885.2 & 271 & 964.7 \\
\hline Trachinotus falcatus & 3 & 3.4 & - & - \\
\hline Umbrina coroides & - & - & 18 & 390.4 \\
\hline Zapteryx brevirostris & - & - & 3 & 855.2 \\
\hline Total & 1190 & $6967 \mathrm{~g}$ & 1589 & 13146g \\
\hline
\end{tabular}

Table 3. Total number of individuals ( $\mathrm{n}$ ) and weight $(\mathrm{g})$ of fish species in Prainha beach in diurnal and nocturnal periods (September/01 to August/02).

\begin{tabular}{|c|c|c|c|c|}
\hline Species & "Diurnal (n) & "Diurnal (g) & "Nocturnal (n) & " Nocturnal (g) \\
\hline Narcine brasiliensis & - & - & 2 & 94.2 \\
\hline Discopyge tschuddi & 1 & 57.7 & - & - \\
\hline Elops saurus & - & - & 1 & 141.8 \\
\hline Albula vulpes & 1 & 12.3 & 2 & 9.0 \\
\hline Opisthonema oglinum & - & - & 5 & 29.4 \\
\hline Harengula clupeola & 1188 & 6.494 .1 & 1318 & 8735.6 \\
\hline Sardinella brasiliensis & - & - & 1974 & 28334.4 \\
\hline Synodus intermedius & - & - & 1 & 61.6 \\
\hline Polydactylus oligodon & 19 & 376.7 & 57 & 491.2 \\
\hline Strongylura timucu & - & - & 2 & 282.0 \\
\hline Atherinella brasiliensis & 2 & 20.1 & - & - \\
\hline Odontesthes bonariensis & 5 & 10.9 & 20 & 67.2 \\
\hline
\end{tabular}


Table 3. Continued.

\begin{tabular}{|c|c|c|c|c|}
\hline Species & Low tide (n) & Low tide (g) & High tide (n) & High tide (g) \\
\hline Sygnathus sp & 1 & 0.2 & - & - \\
\hline Prionotus punctatus & 1 & 2.8 & 1 & 4.2 \\
\hline Dactylopterus volitans & 505 & 4795.6 & 26 & 303.2 \\
\hline Priacanthus cruentatus & - & - & 3 & 64.4 \\
\hline Pomatomus saltatrix & 51 & 132.0 & 299 & 3516.1 \\
\hline Echeneis naucrates & - & - & 1 & 68.1 \\
\hline Caranx latus & 140 & 1838.9 & 16 & 201.0 \\
\hline Chloroscombrus chrysurus & 1 & 42.4 & - & - \\
\hline Oligoplites saurus & - & - & 17 & 727.9 \\
\hline Selene vomer & 26 & 147.4 & 17 & 125.6 \\
\hline Trachinotus carolinus & 3129 & 11389.6 & 2898 & 15865.9 \\
\hline Trachinotus falcatus & 63 & 190.0 & 42 & 282.3 \\
\hline Trachinotus goodei & 557 & 10776.2 & 568 & 11444.1 \\
\hline Lobotes surinamensis & 1 & 12.8 & - & - \\
\hline Boridia grossidens & 15 & 110.5 & 3 & 43.7 \\
\hline Orthopristis ruber & 6 & 435.2 & 54 & 6371.4 \\
\hline Conodon nobilis & 1 & 4.8 & 15 & 147.9 \\
\hline Eucinostomus argenteus & 68 & 1541.4 & 15 & 287.4 \\
\hline Diplodus argenteus & 914 & 1007.6 & 95 & 296.1 \\
\hline Menticirrhus americanus & 12 & 169.7 & 17 & 193.8 \\
\hline Menticirrhus littoralis & 64 & 1011.7 & 83 & 1220.8 \\
\hline Umbrina coroides & 199 & 636.4 & 98 & 1302.6 \\
\hline Stellifer brasiliensis & 5 & 32.6 & 9 & 139.6 \\
\hline Ophioscion punctatissimus & 1 & 14.0 & - & - \\
\hline Pseudupeneus maculatus & - & - & 1 & 15.9 \\
\hline Chaetodipterus faber & 14 & 48.4 & 17 & 121.2 \\
\hline Mugil curema & 48 & 3217.9 & 4 & 700.4 \\
\hline Mugil liza & 2 & 115.8 & 6 & 124.3 \\
\hline Mugil platanus & 1 & 63.3 & - & - \\
\hline Astroscopus ygraecum & 3 & 52.1 & 3 & 44.5 \\
\hline Citharichthys macrops & 1 & 7.7 & - & - \\
\hline Stephanolepis hispidus & 16 & 24.1 & 6 & 7.6 \\
\hline Cyclichthys spinosus & 39 & 259.1 & 31 & 196.0 \\
\hline Total & 7100 & 45051 & 7727 & 82062 \\
\hline
\end{tabular}

At Praia Grande beach, the representative cluster of the CPUE (number of individuals/haul) in diurnal and nocturnal periods showed the formation of several small groups at a similarity level of $50 \%$ (Fig. 5), and no diel or seasonal pattern was observed at this beach. The months from September to December/2001 and May to June/2002 were not included due to the absence of individuals.

As no characteristic groups of a diel or seasonal pattern were formed, it was not possible to identify the species, which contributed to the formation of such groups. 
a

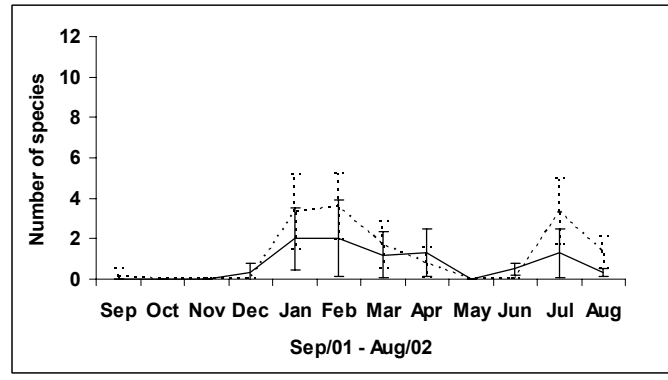

b

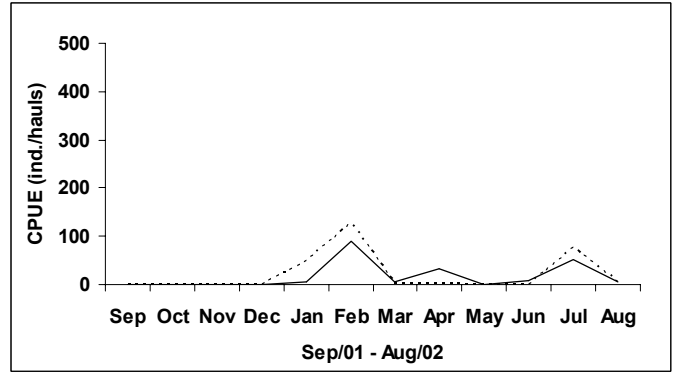

C

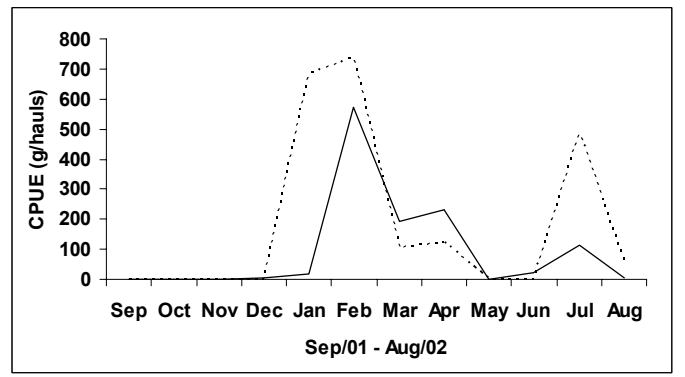

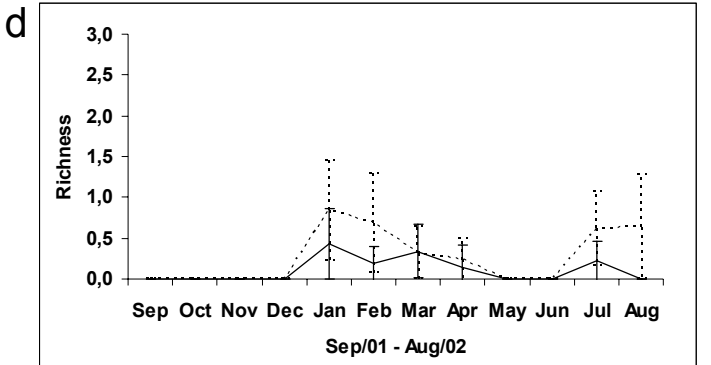
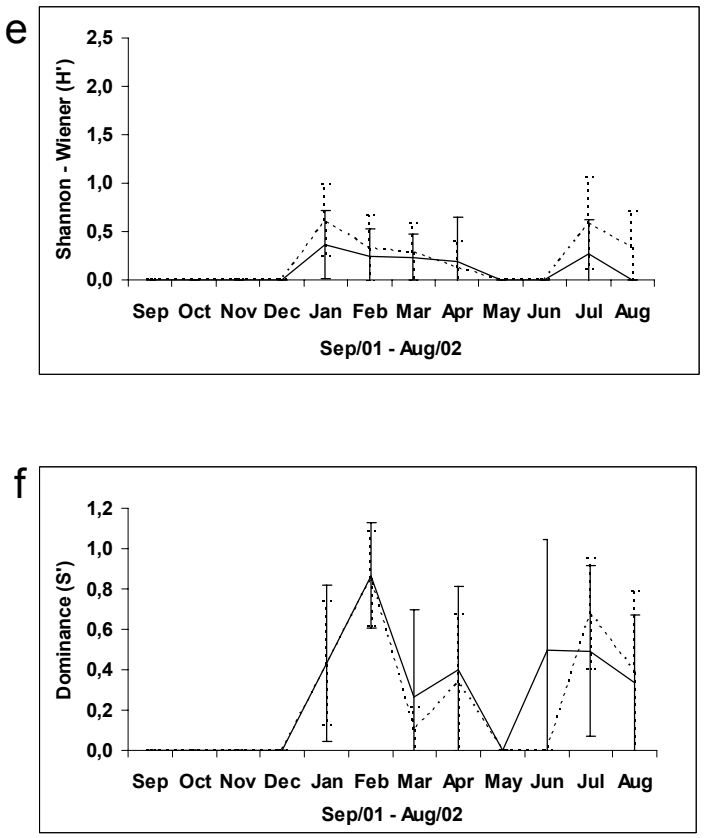

Fig. 4. Temporal variation of average species numbers (a), CPUE ((individuals/haul) (b), CPUE (grams/haul) (c), Margalef's richness (d), Shannon's diversity (e) and Simpson's dominance (f) in diurnal (-) and nocturnal ( ) periods at Praia Grande beach (September/01 to Agust/02).

\section{Prainha Beach}

From September/2001 to August/2002, 14827 fish belonging to 27 families and 45 species were caught at Prainha beach, with a total biomass of $127115 \mathrm{~g}$. In the diurnal period 35 species were sampled which contributed with $48 \%$ of the number of species captured and $35 \%$ of biomass, with seven exclusive ones. In the nocturnal period 37 species were collected, which contributed with $52 \%$ of the total number of individuals and $65 \%$ of biomass, with nine exclusive species (Table 3 ).

The species number showed similar values in diurnal and nocturnal periods (Fig. 6a). The
CPUE (number of individuals/haul) was also similar in both periods, except in December/2001 and June/2002, due to the high number of Diplodus argenteus and Trachinotus carolinus catches in the diurnal and nocturnal periods, respectively (Fig. 6b). Higher CPUE ( $\mathrm{g} /$ haul) occurred in the nocturnal period, mostly in December/2001 and June/2002, with values up to four times higher (Fig. 6c). The great number of Sardinella brasiliensis influenced such difference. Margalef richness, Shannon diversity and Simpson dominance showed quite similar results in both periods, generally higher in summer months (Fig. 6d, 6e, 6f). 


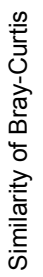

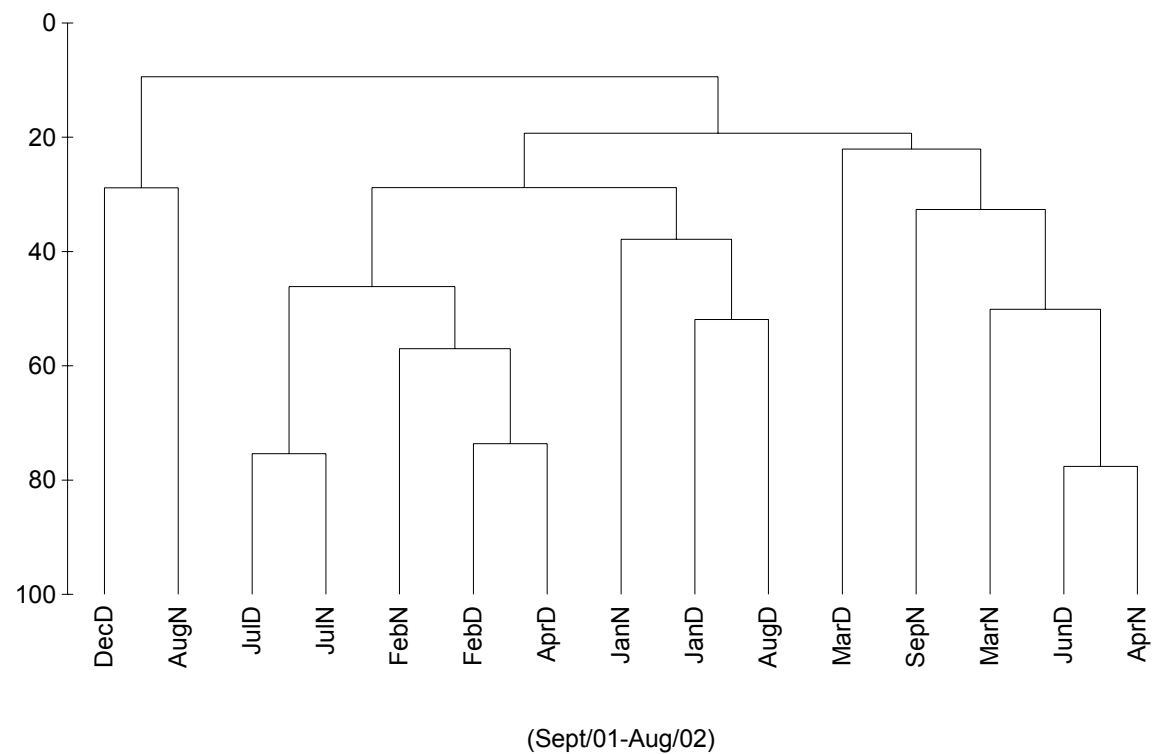

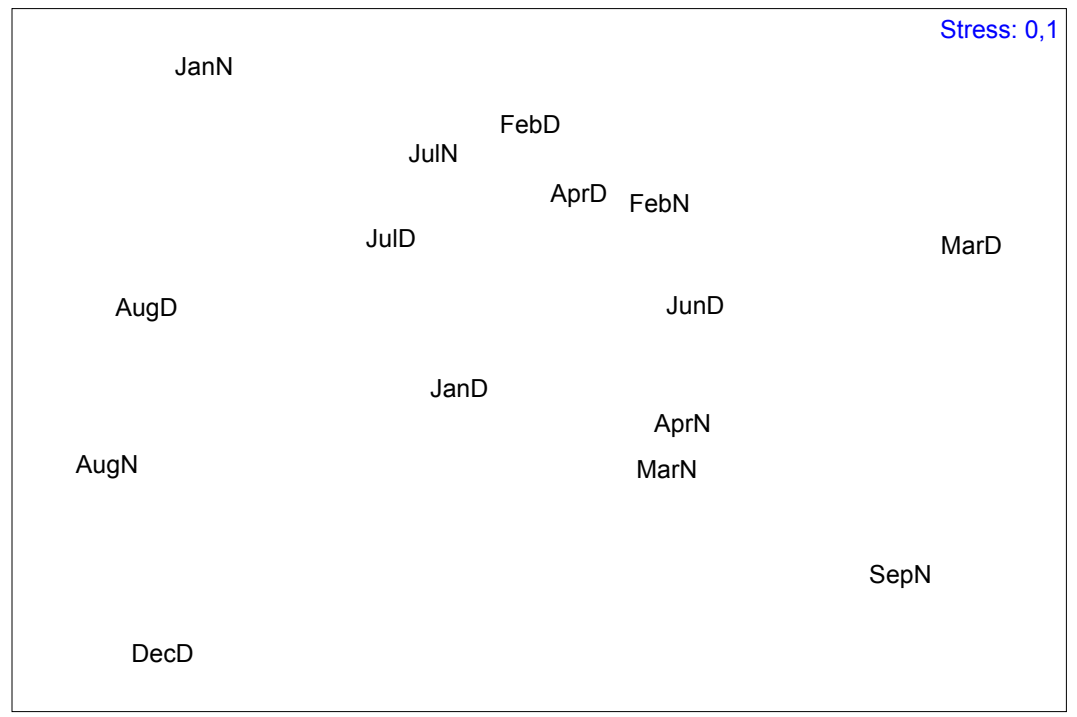

Fig. 5. Cluster analysis (Bray Curtis's similarity coefficient - UPGMA method) and Non-Metric Dimensional Scaling - MDS Ordination method based on CPUE data (individuals/haul) of the main species at Praia dos Grande beach in diurnal and nocturnal periods (September/01 to August/02). The periods from September to December/01 and May to June/02 of both periods were not included due to the absence of captured individuals. 
a

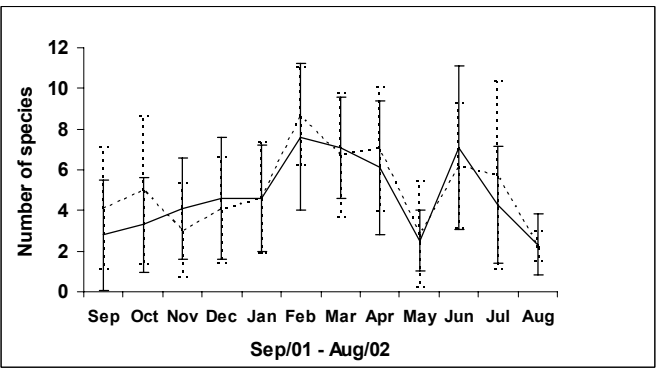

b

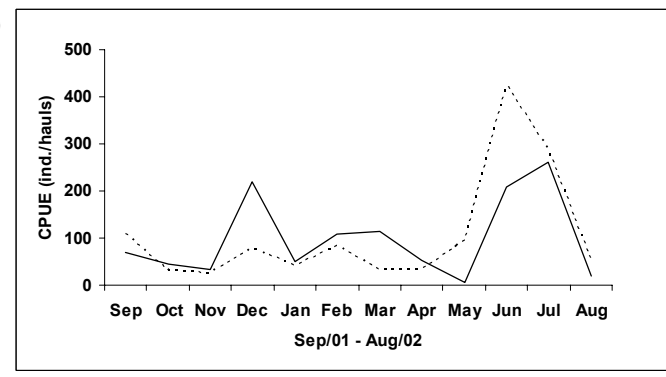

C

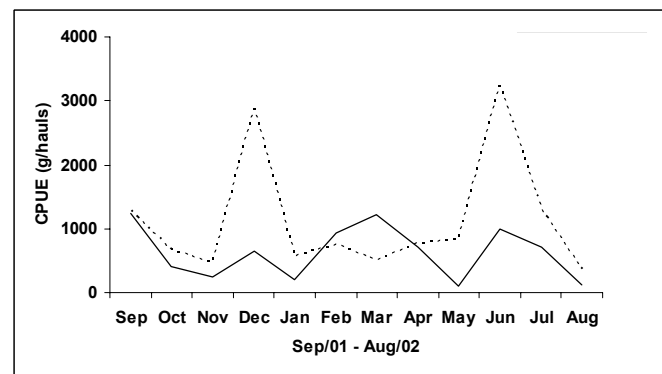

d

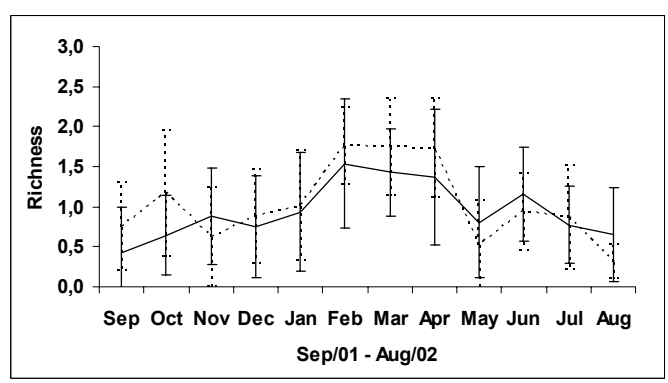

e

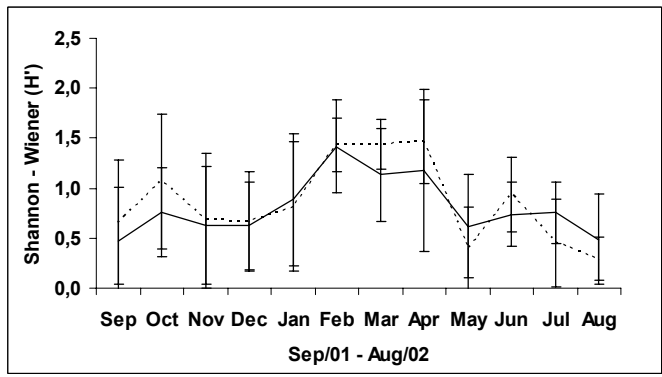

f

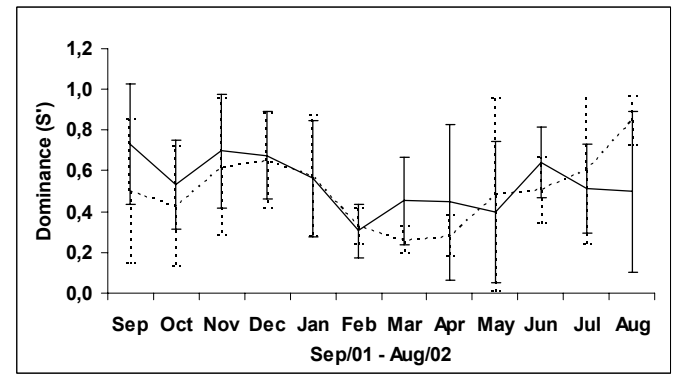

Fig. 6. Temporal variation of average species numbers (a), CPUE (individuals/haul) (b), CPUE (grams/haul) (c), Margalef's richness (d), Shannon's diversity (e) and Simpson's dominance (f) in diurnal (-) and nocturnal ( ) periods at Prainha beach (September/01 to Agust/02).

The representative cluster of CPUE (number of individuals/haul) in the diurnal and nocturnal periods over the 12 months showed the formation of three groups with different months of both periods, indicating the absence of a diel and a seasonal pattern (Fig. 7). In the ordination analysis, the separation of the sampling months in both periods corresponded to the pattern generated by the cluster analysis (Fig. 7). The moderately high stress level of 0.15 suggests that the distances on the plane do not adequately represent the similarities (Fig. 7).
SIMPER analytical method revealed that Groups I and II defined by the cluster analysis presented an average similarity of $66 \%$ and $56 \%$ respectively, with Trachinotus carolinus being responsible for these values. Group III showed the lowest average similarity (39\%), with $H$. clupeola contributing with $46 \%$ of this similarity.

T. carolinus was the species responsible for the highest dissimilarities between groups I and II, and groups I and III. The dissimilarity value between groups II and III was $66 \%$, and $H$. clupeola was the species which most contributed to this dissimilarity. 


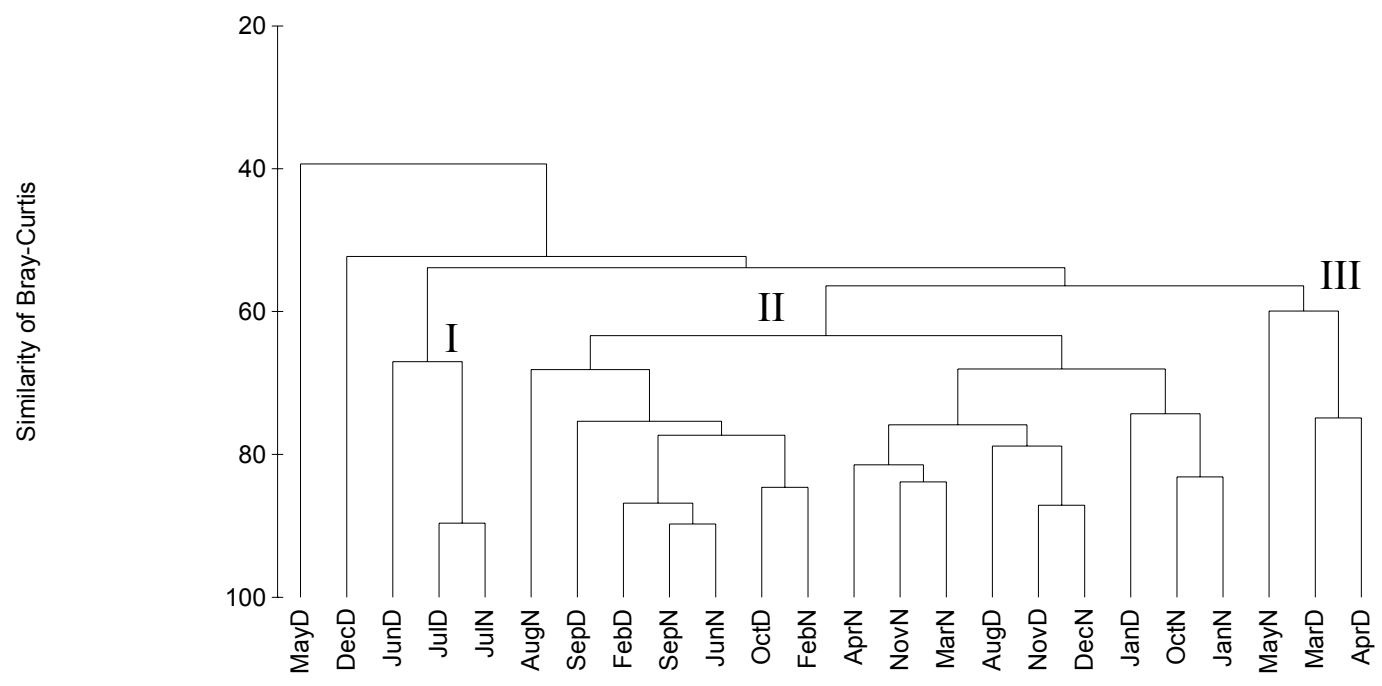

(Sept/01-Aug/02)

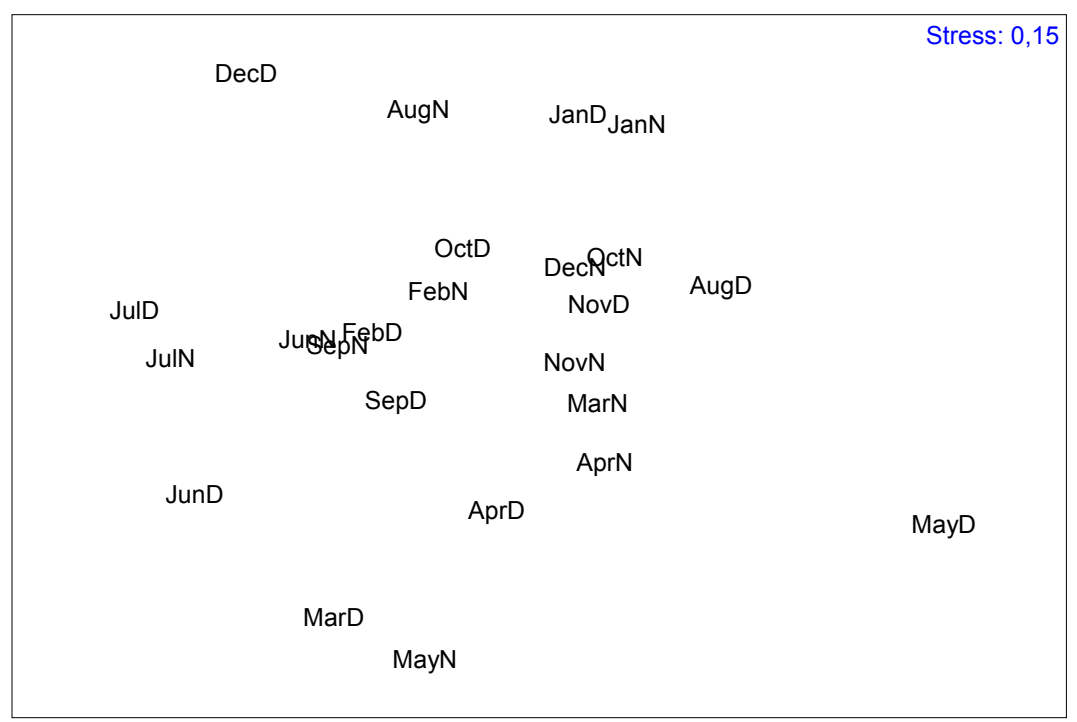

Fig. 7. Cluster analysis (Bray Curtis's similarity coefficient - UPGMA method) and Non-Metric Dimensional Scaling - MDS Ordination method based on CPUE data (individuals/haul) of the main species at Prainha beach in diurnal and nocturnal periods (September/01 to August/02). 


\section{DisCUSSION}

In a daily cycle, some fish species make horizontal or vertical migrations from the feeding area to a shelter zone and vice-versa (WOOTTON, 1995). The selective advantage of a differential temporal organization seems to be a reduction in competition for resources (PALUDETTI, 1988). The behavioral variations in the activity patterns would be a consequences of the endogenous rhythms synchronized by cyclic natural phenomenon. In the marine environment, the main synchronizers (BLAXTER, 1975 apud NEILSON; PERRY, 1990) are the environmental parameter photoperiod, followed mainly by temperature and tide level variations (NEILSON; PERRY, 1990).

At the studied beaches, sampling was designed to contemplate the light parameter through the time variable (diel), which produced diverse and comparable results, partly determined by the behavioral variations of the species. Regarding the community structure, a diel pattern was identified mainly related to the number of individuals, biomass and species richness, which were higher in the nocturnal period at Praia Grande and Prainha beaches and in the diurnal period at Praia dos Anjos beach.

Wardle (1993) observed that the visual stimulus and the avoidance capacity to the nets are fundamental factors in capture success. Behavioral studies show that many fishes are primarily active at night, searching for shelter during the day in inaccessible places to the net or in other protection areas. These fishes are rarely caught in diurnal samplings (QUINN; KOJIS, 1987). In the present study the major fish families presented different behavior in relation to the photoperiod. Pomadaysidae occurred mainly in the nocturnal period, while Gerreidae and Sparidae were captured in the diurnal period. Sciaenidae were recorded in both periods, with no preference. Carangidae occurred in both periods, although mainly in the diurnal one. The species Trachinotus carolinus was characterized as the most abundant during the diurnal samplings, indicating that it mainly uses the sight to capture its benthic prey (MONTEIRO-NETO et al., 1990). The species Sardinella brasiliensis was very abundant mainly in the nocturnal period possibly to avoid predators (MORRISON et al., 2002).

Despite these diel preferences, the same species is frequently recorded in diurnal and/or nocturnal periods by different authors, due to different net sizes or even because these variations are more associated to behavior (horizontal and vertical migrations) of some species for feeding and protection (ALBERT; BERGSTAD, 1993; GIBSON et al., 1996). The fish composition of the surf zone in
Arraial do Cabo did not differ at the three beaches, comparing the diurnal period to the nocturnal one. These results agree with several works (LASIAK, 1984a, b; NASH; SANTOS, 1998; MAES et al., 1999; LAYMAN, 2000, MORRISON et al., 2002; PESSANHA; ARAÚJO, 2003).

The numerical descriptors commonly reveal differences according to the photoperiod. Giannini (1994) in surf zones of Ubatuba, São Paulo, and Pessanha et al. (2003) in Sepetiba Bay, Rio de Janeiro, verified a higher density in the diurnal period and a significantly higher biomass in the nocturnal ones. According to the authors, the horizontal migration of larger individuals in different night hours and net avoidance during the day could explain the diel variation.

At Prainha beach, we observed that the highest density and biomass occurred in the nocturnal period. The beach is exposed to East and Northeast winds, that favors the retention of planktonic material, facilitating larval settlement and the arrival of food, mainly copepodes. The presence of seasonal algae beds may also favor the fish concentration since it offers shelter against predators and gathers an abundant epifauna of invertebrates that are consumed by the fish (ORNELLAS; COUTINHO, 1998). It is suggested that a few larger piscivorous species such as Pomatomus saltatrix move to shallower waters near the Sargassum bed mainly at night, in order to access important food concentration especially epi and endofaunal prey of the surf zone. According to LASIAK (1986), NELSON (1986) and ABOU-SEEDO et al. (1990), the feeding pattern is related to the fish activity cycle, including the searching food period and movement to the feeding areas.

BLABER et al. (1995) and GRAY et al. (1998) studying the fish associations in algae beds verified that several species showed a diurnal pattern with higher densities than in the nocturnal period, due to the migration of individuals larger than $100 \mathrm{~mm}$. These authors, when comparing fish communities with and without gramineous beds verified, higher fish abundance in the former ones. The same occurred at Prainha beach (with macroalgae beds), where the density and biomass were two times higher than at Praia Grande and Praia dos Anjos beaches (without macroalgae beds).

In contrast to the above-mentioned works, at Praia dos Anjos beach, the number of individuals and biomass were higher in the diurnal period, which might be caused by the movement of some species at night to deeper areas in search for food or predator avoidance as observed by ABOU-SEEDO et al. (1990).

The absence of algae beds at Praia Grande beach together with the intense movement of cold 
water, typical of the upwelling process, makes larvae settlement difficult due to the offshore transport. It should be also emphasize the lowest temperatures in this beach, below the optimum range from $18^{\circ}$ to $20^{\circ} \mathrm{C}$-for the growth in the juvenile phase (WILBER et al., 2003). Besides, the higher wave exposure in relation to the other beaches could have contributed to the low abundance and diversity of fish and higher dominance making the environment more adverse except for opportunistic and resistant species such as Harengula clupeola and Trachinotus carolinus, which were dominant at Praia Grande.

Considering the fish community structure at the three beaches, the diel distribution pattern was expected for tropical regions, with high species richness, few dominant or abundant species and a high number of rare ones (LOWE-MCCONNELL, 1990).

The occurrence of higher richness, density and abundance values in the nocturnal period might be considered a common pattern to different environments of the coastal zones (CLARK et al., $1996 \mathrm{a}, \mathrm{b})$. We believe that the main factor is the protection against predators due to the lack of light, which would make the visualization of the prey difficult as pointed out by Wardle (1993).

The hypothesis that the fish community shows a diel variation in the surf zone at Arraial do Cabo beaches was partly accepted because it occurred mainly for some species but not for the whole fish assemblage.

Biological interactions (mainly predation), behavioral aspects (e.g. displacement and net avoidance) and local characteristics (macroalgae beds, upwelling and wave exposure stress) might explain some of the diurnal differences in the abundance and richness of the surf zone fish community at Arraial do Cabo.

\section{REFERENCES}

ABOU-SEEDO, F. CLAYTON, D. A.; WRIGHT, J. M. Tidal and turbidity effects in the shallow-water fish assemblage of Kwait Bay. Mar. Ecol. Progr. Ser., v.65, p. 213-233, 1990.

AIDAR, E., GAETA, S. A.; GIANESELLA-GALVÃO, S. M. F., KUTNER, M. B. B. ; TEIXEIRA, C. Ecossistema Costeiro Subtropical: Nutrientes Dissolvidos, Fitoplâncton e Clorofila-a e suas Relações com as Condições Oceanográficas na Região de Ubatuba (SP). Publção esp. Inst. oceanogr., S. Paulo, n. 10:9-43, 1993.

AUYVAZIAN, S. G. ; HYNDES, G. A. Surf-zone fish assemblages in south-western Australia: do adjacent nearshore habitats and warm Leewin Current influence the characteristics of the fish fauna? Mar. Biol., v. 122 p. 527-536, 1995.
ALBERT, O. T. ;BERGSTAD, O. A. Temporal and spatial variation in the species composition of trawl sample from demersal fish community. J. Fish Biol., v. 43 . p. 209-222, 1993. ( Supplement A),

ARAÚJO, I. G.; COSTA DE AZEVEDO, M. C. Assemblages of southeast-south brazilian coastal system based on the distribution of fishes. Estuar. coast. Shelf Sci.,, v. 52, p. 729-738, 2001.

BARREIROS, J. P.; FIGNA, V.; HOSTIM-SILVA, M. \& SANTOS, R. S. Diel seasonality of a shallow water fish assemblage in a sandy beach at Canto Grande, Santa Catarina, Brasil. J. Coast. Res., v. 42, p. 79-83, 2004.

BLABER, S. J. M.; BLABER, T. G. Factors affecting the distribution of juvenile estuarine and inshore fish. J. Fish Biol., v. 17, p. 143-162, 1980.

BLABER, S. J. M.; BREWER, D.T.; SLINI J. P. Fish communities and nursey role of the shallow inshore waters of a tropical bay in the Gulf of Carpentaria, Australia. Estuar. coast. Shelf Sci., v. 40, p. 177-193, 1995.

CASTRO, C. B.; ECHEVERRIA, C. A.; PIRES, D. O.; MASCARENHAS, B. J.; FREITAS, S G.. Distribuição de cnidaria e equinodermata no infralitoral de costões rochosos de Arraial do Cabo, Rio de Janeiro, Brasil. R. bras. Biol.,v. 55, p. 471-480, 1995.

CHAVES, P. T.; BOUCHEREAU, J. L. Trophic organization and functioning of fish population in the Bay of Guaratuba, BR, on the basis of a trophic contribuction factor. Acta adriat., v.45, 83-94, 2004.

CLARK, K. R. ;WARWICK, R. M. 1994. Change in marine communities: an approach to statistical analysis and interpretation. Plymouth: Plymouth Marine Laboratory. $859 \mathrm{p}$.

CLARK, B. M, BENNETT, S. J.; LAMBERTH, S. J.. Temporal variations in surf zone fish assemblages from False Bay, South Africa. Mar. Ecol. Prog. Ser., v.131,p.35-47, 1996a.

CLARK, B. M, BENNETT, S. J.; LAMBERTH, S. J. Factors affecting spatial variability in seine net catches of fish in the surf zone of False Bay, South Africa. Mar. Ecol. Prog. Ser., v. 131, p. 7-34, 1996 b.

CUNHA, L. P. R. Variação sazonal da distribuiçãa, abundância e diversidade dos peixes na zona de arrebentação da praia do Cassino, RS, Brasil. $47 \mathrm{p}$. Dissertação (Mestrado)-UFRJ, Rio de Janeiro, 1981.

FAGUNDES NETTO, E. B.; GAELZER, L. R. Associações de peixes bentônicos e demersais na região do Cabo Frio, RJ, Brasil. Nerítica, v. 6, n. 1-2, p. 39-156, 1991.

FERREIRA, C. E. L., GONÇALVES, J. E. A.; COUTINHO, R. I. Metodologias em estudos de comunidades de peixes em costões rochosos: Questões básicas e fundamentais. In: SIMP. ECOSSIST. COSTA BRASIL., 3., 1994. Anais... p. 319-329.

FERREIRA, C. E. L.; PERET, A. C. ; COUTINHO, R. Seasonal grazing rates and food processing by tropical herbivorus fishes. J. Fish Biol., v. 53, p. 222-235, 1998.

FERREIRA, C. E. L.; GONÇALVES, J. E. A. ; COUTINHO, R. Comunity structure of fishes and habitat complexity on a tropical rocky shore. Environ. Biol. Fishes, v. 61, p. 353-369, 2001.

FIGUEIREDO, J.L.; MENEZES, N.A. Manual de peixes marinhos do sudeste do Brasil, II : Teleostei (1). São Paulo: Museu de Zoologia da Universidade de São Paulo, 1978. $110 \mathrm{p}$. 
FIGUEIREDO, J.L.; MENEZES, N.A. Manual de peixes marinhos do sudeste do Brasil, II. Teleostei (2). São Paulo, Museu de Zoologia da Universidade de São Paulo. 1980. 90 p

FIGUEIREDO, J.L.; MENEZES, N.A. Manual de peixes marinhos do sudeste do Brasil. II Teleostei (5). São Paulo, Museu de Zoologia da Universidade de São Paulo, 2000. $116 \mathrm{p}$.

GAELZER, L. R. Estrutura da comunidade de peixes em praias arenosas na região de Arraial do Cabo, RJ: Variação nictemeral e influência da maré. Tese (Doutorado em Biociências e Biotecnologia)- 133 p. Universidade Estadual do Norte Fluminense (UENF), 2005 .

GAELZER, L. R.; ZALMON, I. R. The Influence of wave gradient on the ichthyofauna of Southeastern Brazil: focusing the community structure in surf-zone. $\mathbf{J}$. coast. Res., v. 35, p. 456-462, 2003.

GIANNINI, R. Estrutura das comunidades de peixes da zona de arrebentação de praias arenosas do litoral do Estado de São Paulo, Brasil. 139 p. Tese (Doutorado)Instituto Oceanográfico, USP, São Paulo, 1994.

GIANNINI, R; PAIVA-FILHO, A. M. Análise comparativa da ictiofauna da zona de arrebentação de praias arenosas do Estado de São Paulo, Brasil. Bolm Inst. oceanogr., S Paulo, v. 43, n. 2, p. 41-152, 1995.

GIBSON, R. N.; ROBB, L.; ANSELL, A. D. Tidal, diel and longer term changes in the distribution of fishes on a Scottish sandy beach. Mar. Ecol. Prog. Ser., v. 130, p. 1-17, 1996.

GODEFROID, R. S.; HOFSTAETTER, M.; SPACH, H. L. Structure of the fish assemblage in the surf zone of the beach at Pontal do Sul, PR. Neritica, v. 11, p. 77-93, 1997.

GODEFROID, R. S.; SPACH, H. L.; SANTOS, C.; MAC LAREN, G. N. Q.; SCHWARZ JR, R. Mudanças temporais na abundância e diversidade da fauna de peixes do infralitoral raso de uma praia, sul do Brasil. Iheringia - Serie Zoologia, v.94, n. 1, p. 95-104, 1997.

GOMES, M. P.; CUNHA, M. S.; ZALMON, I. R. Spatial and temporal variations of diurnal ichthyofauna on surf zone of São Francisico do Itabapoana beaches, RJ, Brazil. Brazil. Arqs Biol. Techn., v. 46, n. 4, p. 653-664, 2003.

GRAY, C. A.; CHICK, R. C. ; McElligOTT, D. J. Diel changes in Assemblages of Fishes Associated with Shallow Seagrass and Bare Sand. Estuar. coast. Shelf Sci., v. 46, p. 849-859, 2003.

GUIMARANES, M. A.; COUTINHO, R. Spatial and temporal variation of benthic marine algae at Cabo Frio upwelling region, Rio de Janeiro, Brazil. Aquatic. Bot., v.52, p.83-299, 1996.

HOBSON, E. S. Diurnal - nocturnal activity of some inshore fishes in the Gulf of California. Copeia,v. 3, p. 291-302, 1965.

HORN, M. H. 1980. Diel seasonal variation in abundance and diversity of shallow-water fish populations in Morro Bay, California. Fish. Bull., v. 78, n. 3, p. 759-770.

LASIAK, T. A. Structural aspects of the surf zone fish assemblage at King's Beach, Algoa Bay, South Africa: Long - term fluctuations. Estuar. coast. Shelf Sci., v.18, n. 4, p. 459-483, 1984a.

LASIAK, T. A. Structural aspects of the surf zone fish assemblage at King's Beach, Algoa Bay, South Africa:
Short - term fluctuations. Estuar. coast. Shelf Sci., v. 18 , n. 4, p. 347-360, 1984 b.

LASIAK, T. A. Juveniles, food and the surf-zone habitat: implications for teleost nursery areas. S. Afr. J. Zool., v. 21, p. 1-56, 1986.

LAYMAN, C. A. Fish assemblage structure of the shallow ocean surf-zone on the eastern shore of Virginia Barrier Islands. Estuar. coast. Shelf Sci., v. 51 , n. 2, p. 201213, 2000.

LOPES, P. R. D.; OLIVEIRA-SILVA, J. T.; SENA, M. P.; SILVA, I. S.; VEIGA, D. C. M.; SILVA, G. R.; SANTOS, R. C. L. Contribuição ao conhecimento da ictiofauna da praia de Itapema, Santo amaro da Purificação, Baía de Todos os Santos, BA. Acta biol. Leopold., v. 21 ,1, p. 99-105, 1999.

LOWE-MCCONNELL, R. H. Estudos ecológicos de comunidades de peixes tropicais. São Paulo EDUSP, 1999. $534 \mathrm{p}$.

MAES, J.; PAS, J.; TAILLIEU, A.; VAN DAMME, P. A.; OLLEVIER, F. Diel changes in the vertical distribution of juvenile fish in the Zeeschelde Estuary. J. Fish Biol., 54: 1329-1333, 1999.

MENEZES, N.A.; FIGUEIREDO, J.L. Manual de peixes marinhos do sudeste do Brasil, II: Teleostei (3). São Paulo: Museu de Zoologia da Universidade de São Paulo, 1980. 96 p.

MENEZES, N.A.; FIGUEIREDO, J.L. Manual de peixes marinhos do sudeste do Brasil, II: Teleostei (4). São Paulo: Museu de Zoologia da Universidade de São Paulo, $1985.105 \mathrm{p}$.

MIRANDA, L. B.; KATSURAGAWA, M. Estrutura Térmica na Região Sudeste do Brasil (outubro-novembro de 1988). Publção esp. Inst. oceanogr., S Paulo, n. 8, p. 1$14,1991$.

MONTEIRO-NETO, C.; BLACHER, C.; LAURENT, A. A. S.; SNIZEK, F. N.; CANOZZI, M. B. ; TABAJARA, L. L. C. Estrutura da comunidade de peixes de águas rasas na região de Laguna, Santa Catarina, Brasil. Atlântica, v. 12 , n. 2, p. 53-69, 1990.

MONTEIRO-NETO, C.; MUSICK. J. A. Effects of beach seine on asessment of surf zone fish communities. Atlântica, v. 16, p. 23-29, 1994.

MORRISON, M. A.; FRANCIS, B. W.; HARTILL, B. W.; PARKINSON, D. M. Diurnal and tidal variation in the abundance of the fish fauna of a temperate tidal mudflat. Estuar. coast. Shelf Sci., v. 54, p.793-807, 2002.

NASH, R. D. M.; SANTOS, R. S. Seasonality in diel catch rate of small fishes in a shallow-water fish assemblage at Porto Pim Bay, Faial, Azores. Estuar. coast. Shelf Sci., v. 47 , p. 319-328, 1998.

NEILSON, J. D.; PERRY, R. I. Diel vertical migrations of marine fishes: an obligate or a facultative process? Adv. mar. Biol., v.26, p. 115-168, 1990.

NELSON, W. O. Predation and prey population variation in a high energy sand beach macrofaunal community. Ophelia, v. 26:305-316, 1986.

ORNELLAS, A. B. ; COUTINHO, R. Spatial and temporal patterns of distribution and abundance of a tropical fish assemblage in a seasonal Sargassum bed, Cabo Frio Island, Brazil. J. Fish Biol., v. 53, p. 198-208, 1998.

PAIVA- FILHO, A. M. ;TOSCANO, A. P. Estudo comparativo e variação sazonal da ictiofauna na zona entremarés do Mar Casado-Guarujá e Mar Pequeno-São 
Vicente, SP. Bolm Inst. oceanogr., S. Paulo, v. 35, n. 2, p. 153-165, 1987.

PALUDETTI, L. A. A origem dos ritmos biológicos e o seu papel na evolução e adaptação dos seres vivos. In: CIPOLLA-NETTO, J; MARQUES, N.;MENNABARRETO, L.S. (Ed.). Introdução ao estudo da cronobiologia. São Paulo: Ícone; EDUSP, 1988. p.2950.

PATERSON, A. W.; WHITFIELD, A. K. Do shallow-water habitats function as refuge for juvenile fishes? Estuar. coast. Shelf Sci., v.51, p. 359-364, 2000.

PEREIRA, L. E. Variação diurna e sazonal dos peixes demersais na barra do estuário da Lagoa dos Patos, RS Atlântica, v. 16:5-21. 1994.

PESSANHA, A. L. M.; ARAÚJO, F.G.; AZEVEDO, M. C. C.; GOMES, I. D. Diel and seasonal changes in the distribuition of fish on a southeast Brazil sandy beach. Mar. Biol., v. 143, p.1047-1055, 2003.

PESSANHA, A. L. M.; ARAÚJO, F.G. Spatial, temporal and diel variations of fish assemblages at two sandy beaches in the Sepetiba Bay, Rio de Janeiro, Brazil. Estuar. coast. Shelf Sci., v. 57, p. 817-828, 2003.

POTTS, G. W. Crespuscular behaviour of marine fishes. In: HERRING, P. J.; CAMPBELL, A. K.; WHITFIELD, W. \& MADDOCK, L. (Ed.) Light and life in the sea. Cambridge: Cambridge Univ. Press, 1990. p. 221-227.

QUINN, N. J.; KOJIS, B. L. The influence of diel cycle, tidal direction and trawl alignmente on beam trawl catches in an equatorial estuary. Environ. Biol. Fishes, v.19, n.4, p.297-308, 1987.

SAUL, A. C.; CUNNINGHAM, P. T. M. Comunidade ictiofaunística da Ilha do Bom Abrigo, Cananéia, São Paulo, Brasil. Arq. Biol. Tecnol., v. 38, n. 4, p. $1053-$ 1069, 1995.
SPACH, H. L.; GODEFROID, R. S.; SANTOS, C.; SCHWARZ JR, R. ; QUEIROZ, G. M. L. N. Temporal variation in fish assemblage composition on a tidal flat. Braz. J. Oceanogr., v. 52, n.1, p.47-58, 2004.

TEIXEIRA, R. L.; FALCÃO, G. A.; MELLO, S. C. Ocorrência e alimentação de juvenis de Sciaenidae (Pisces: Perciformes) nas zonas de arrebentação de praias em Maceió, Brasil. Atlântica, v. 4, p. 29-42, 1992.

VALENTIN, J. L. Analyse des paramèters hydrobiologiques dans la remontée de Cabo Frio (Brésil). Mar. Biol., v. 82:259-276, 1984.

VIANNA, M. Physiographic influence in the strucuture of the suprabenthic fish assemblage in the rocky shore of Arraial do Cabo, Rio de Janeiro, Brazil. Bolm Inst. Pesca., v. 24, p. 25-35, 1997.

WARDLE, C.S. Fish behaviour and fishing gear. In: PITCHER, T. (Ed.). Behaviour of teleost fishes. London: Chapman and Hall, 1993. 715 p.

WILBER, D. H.; CLARKE, D.G.; BURLAS, H; WILL, R. J. Spatial and temporal variability in surf zone fish assemblages on the coast of northern New Jersey. Estuar. coast. and Shelf Sci., v. 56, p. 291-304, 2003.

WOOTTON, R. J. Ecology of teleost fishes. $2^{\text {nd }}$. ed. London: Chapman \& Hall, 1995. 404 p.

ZAR, J. H.. Biostatistical analysis. $2^{\text {nd }}$. ed. Englewood Cliffs, N. J.: Prentice Hall, 1984. 718 p.

(Manuscript received 05 April 2006; revised 05 June 2007; accepted 12 July 2007) 